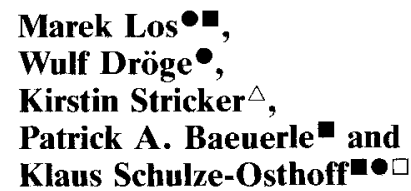

Division of Immunochemistry ${ }^{\bullet}$ and Division of Immunogenetics $\triangle$, Deutsches Krebsforschungszentrum, Heidelberg and Institute of Biochemistry ${ }^{\square}$, University of Freiburg, Freiburg

\section{Hydrogen peroxide as a potent activator of T lymphocyte functions}

During inflammatory processes infiltrating cells produce large amounts of reactive oxygen intermediates (ROI). Increasing evidence suggests that ROI besides being cytotoxic may act as important mediators influencing various cellular and immunological processes. In this study, we have investigated the effects of hydrogen peroxide on several aspects of lymphocyte activation. In ESb-L T lymphoma cells, micromolar concentrations of hydrogen peroxide rapidly induced activation of the transcription factor NF- $x \mathrm{~B}$, whereas DNAbinding activity of the transcription factor AP-1 was virtually not affected. In addition, hydrogen peroxide induced early gene expression of interleukin-2 (IL-2) and the IL-2 receptor $\alpha$ chain. The stimulation of IL-2 expression was found to be conferred by a $x \mathrm{~B}$-like cis-regulatory region within the IL-2 gene promoter. In contrast to these activating effects, addition of hydrogen peroxide was largely inhibitory on cell proliferation which is consistent with a general requirement of thiol compounds for lymphocyte proliferation. However, hydrogen peroxide significantly increased $\mathrm{T}$ cell proliferation when applied for a short period under reducing conditions. These data indicate that ROI may act as an important competence signal in $\mathrm{T}$ lymphocytes inducing early gene expression as well as cell proliferation.

\section{Introduction}

$T$ lymphocyte activation is an essential part of the immune reaction. Upon stimulation with antigen and accessory molecules T cells enter the cell cycle and proliferate leading to clonal expansion of antigen-specific T cells. Proliferation of $\mathrm{T}$ lymphocytes after activation requires both the secretion of interleukin-2 (IL-2) and expression of the highaffinity IL-2 receptor (IL-2R) [1].

Neutrophils participate in the immune response by producing large amounts of reactive oxygen intermediates (ROI) in response to proinflammatory stimuli [2]. Limited amounts of ROI are continuously formed during various electron transfer reactions in every cell type. Recent evidence suggests that ROI may be not only part of an antimicrobial defense mechanism but may also be involved in signal transduction of immunoregulatory processes $[3,4]$. For instance, ROI have been shown to induce the expression of cytokines [5-7], adhesion molecules [8, 9] and proto-oncogenes $[10,11]$. We and others have demonstrated that gene expression in response to ROI can be attributed to the activation of certain transcription factors including NF- $x \mathrm{~B}$ and AP-1, both of which are activated under prooxidant conditions [12-14]. Moreover, activation

[I 13590]

\footnotetext{
$\square$ Supported by a fellowship from the Bundesministerium für Forschung und Technologie (AIDS Stipendium).
}

Correspondence: Klaus Schulze-Osthoff, Division of Immunochemistry, Deutsches Krebsforschungszentrum, Im Neuenheimer Feld 280, D-69120 Heidelberg, FRG (Fax: +49-6221-423746)

\begin{abstract}
Abbreviations: CAT: Chloramphenicol acetyltransferase IL-2-R: Interleukin-2 receptor ROI: Reactive oxygen intermediates TPA: Tetradecanoyl phorbol acetate
\end{abstract}

Key words: Interleukin-2 / Proliferation / Reactive oxygen intermediates / $\mathrm{T}$ cell of NF- $x \mathrm{~B}$ by all stimuli known so far, including cytokines, phorbolesters or lipopolysaccharide, was found to be inhibited by antioxidants [14-18]. These observations support the idea that ROI exert an important role in gene expression and that several physiological stimuli apparently utilize ROI as messenger molecules for signal transduction.

A number of indications further suggest that ROI may be involved in lymphocyte activation. Among others, activation of $T$ cells by the costimulatory molecule CD28 has been shown to involve oxidative signaling and to be abrogated by antioxidants $[19,20]$. In addition, intracellular ROI formation has been proposed to be required for lymphocyte proliferation since various antioxidants inhibit cell growth in response to mitogens $[4,21,22]$. By contrast, the proliferative response in other situations, such as in mixed lymphocyte reactions or IL-2-dependent cell growth, was found to be inhibited by prooxidants and promoted by antioxidants and exogenous thiols [5, 23-28]. Thus, it appears that certain lymphocyte functions are obviously promoted by prooxidant conditions whereas others are inhibited, suggesting the requirement of a delicate redox balance.

In the present study we have analyzed the effects of hydrogen peroxide on various lymphocyte functions. Using ESb-LT lymphoma cells we show that micromolar concentrations of hydrogen peroxide rapidly induce the activation of NF- $x \mathrm{~B}$ and cause an increase of expression of the IL-2 and IL-2R $\alpha$ chain genes. Expression of IL-2 in response to hydrogen peroxide was found to be conferred by a $x \mathrm{~B}$ cis-regulatory element within the IL-2 promoter. In contrast to these activating effects, addition of hydrogen peroxide was largely inhibitory on cell proliferation. However, we observed that hydrogen peroxide significantly enhanced $T$ cell growth when applied for a short period under reducing conditions. These data suggest that $\mathrm{ROI}$ may act as competence signal involved in the regulation of cell cycle entry and in the control of early gene expression in T lymphocytes. 


\section{Materials and methods}

\subsection{Cell culture}

The mouse T cell lymphoma line ESb-L was grown in RPMI-1640 supplemented with $5 \%$ heat-inactivated fetal calf serum, $30 \mu \mathrm{M} 2$-mercaptoethanol and antibiotics. ESb$\mathrm{L}$ cells were derived from the methylcholanthrene-induced T cell lymphoma L 51874 [29]. The IL-2-dependent cell line CTLL-2 was cultured in the same medium containing $50 \mathrm{U} / \mathrm{ml}$ of recombinant IL-2 (kindly provided by Perkin Elmer-Cetus, Überlingen, FRG).

\subsection{Proliferation assay}

ESb-L cells $\left(5 \times 10^{3} / 100 \mu \mathrm{l}\right)$ were seeded in triplicates into 96-well round-bottom microtiter plates and stimulated with serial dilutions of hydrogen peroxide. Catalase (Sigma, Deisenhofen, FRG) was used at a concentration of $15000 \mathrm{U} / \mathrm{ml}$. After incubation for $42 \mathrm{~h}, 1 \mu \mathrm{Ci}$ of $\left[{ }^{3} \mathrm{H}\right]$ thymidine (Amersham, Braunschweig, FRG) was added to each well and proliferation continued for $6 \mathrm{~h}$. Cells were then harvested onto glass fiber filters and tritium incorporation was determined using a 1205 Betaplate (Pharmacia, Freiburg, FRG) liquid scintillation counter.

\subsection{Measurement of IL-2R expression}

Expression of the IL-2R was determined by FACS analysis. Briefly, cells were cultured for the indicated times in the presence of hydrogen peroxide and stained with a phycoerythrin-labeled anti-mouse IL-2R $\alpha$ chain monoclonal antibody (Gibco BRL, Karlsruhe, FRG) at $4{ }^{\circ} \mathrm{C}$. After 30 min, cells were washed with PBS and analyzed using a FACScan (Becton Dickinson, Heidelberg, FRG) flow cytometer.

\subsection{Measurement of IL-2 production}

IL-2 in culture supernatants was assayed by the ability to stimulate DNA synthesis of the IL-2-dependent cell line CTLL-2. Supernatants were taken from 48-h cultures incubated with several concentrations of hydrogen peroxide. The samples were titrated in triplicates by serial $\log _{2}$ dilutions in 96 -well plates $(100 \mu \mathrm{l} / \mathrm{w})$. Then, $100 \mu \mathrm{l}$ of the cell suspension $\left(5 \times 10^{3}\right.$ cells $)$ was added. Proliferation was determined after $24 \mathrm{~h}$ by pulsing the cells with $1 \mu \mathrm{Ci} /$ well of $\left[{ }^{3} \mathrm{H}\right]$ thymidine. IL-2 activity is expressed in international units $(\mathrm{IU}) / \mathrm{ml}$ using a recombinant mouse IL-2 standard.

\subsection{Detection of IL-2 specific mRNA expression by RT-PCR}

Expression of IL-2-specific mRNA was determined by reverse transcribed polymerase chain reaction. Cells were treated for $6 \mathrm{~h}$ or $12 \mathrm{~h}$ with $50 \mu \mathrm{M}$ hydrogen peroxide and total RNA was isolated using the guanidinium isothiocyanate/cesium chloride method. After annealing with random hexamer primers (Perkin Elmer-Cetus), $1 \mu \mathrm{g}$ RNA was reversed transcribed with $250 \mathrm{U}$ M-MuLV reverse transcriptase (Biolabs) for $1 \mathrm{~h}$ at $37^{\circ} \mathrm{C}$ in $25-\mu \mathrm{l}$ volume of $50 \mathrm{mM}$
Tris- $\mathrm{HCl}, \mathrm{pH} 8.3,8 \mathrm{~mm} \mathrm{MgCl}, 30 \mathrm{~mm} \mathrm{KCl}, 10 \mathrm{~mm}$ DTT and RNasin. Two microliters of the reaction was then amplified in a thermocycler (Stratagene, Heidelberg) in a $50 \mu$ volume containing $200 \mu \mathrm{M}$ of each dNTP, $1 \mathrm{U}$ of Deep Vent DNA polymerase (Biolabs), $500 \mathrm{nM}$ of the IL2-specific primers, $4 \mathrm{mM} \mathrm{MgCl}_{2}$ and a buffer supplied by the manufacturer. Cycle temperatures were $94^{\circ} \mathrm{C}(1 \mathrm{~min})$ for denaturation, $60^{\circ} \mathrm{C}(1 \mathrm{~min})$ for annealing and $75^{\circ} \mathrm{C}(45 \mathrm{~s})$ for the extension reaction. Before the first cycle a denaturing step for $5 \mathrm{~min}$ at $94^{\circ} \mathrm{C}$ was included and after 29 cycles the extension was prolonged for $2 \mathrm{~min}$. The upstream (5'-GACCCGTACAAGACCTAAACTGAG-3') and downstream primer (5-TGATGGACCTACAGGAGCTCCTGAG-3') result in an expected 167-bp product. One third of the PCR volume was run on $1.5 \%$ agarose gel. After transfer to a nylon membrane and UV cross-linking, filters were hybridized at $42{ }^{\circ} \mathrm{C}$ with a ${ }^{32} \mathrm{P}$-labeled IL-2 cDNA probe in $50 \mathrm{~mm}$ Tris-HCl buffer $\mathrm{pH} 7.5$ containing $0.1 \%$ sodium pyrophosphate, $1 \%$ SDS, $0.2 \%$ polyvinylpyrrolidone, $5 \mathrm{mM}$ EDTA, $0.2 \% \mathrm{BSA}, 50 \%$ formamide and $10 \%$ dextransulfate. After several washings filters were exposed to an X-ray film. The specificity of the amplication reaction was verified by direct $\mathrm{cDNA}$ sequencing of the reaction product.

\subsection{IL-2 reporter gene assays}

Responsiveness of the IL-2 promoter to hydrogen peroxide and identification of cis-regulatory elements were investigated using chloramphenicol acetyltransferase (CAT) assays. Construction of the chimeric reporter gene plasmids has been described [30]. Plasmid pIL2-293 contains the -293 to $-7 \mathrm{bp}$ region of the murine IL-2 promoter linked to the CAT gene in the plasmid pBLCAT2. The deletion constructs pIL2-237 and pIL2-100 contained the region flanking from position -237 to -7 and -100 to $-7 \mathrm{bp}$, respectively. Plasmid pIL2-xBM carried a site-specific mutation of the $x \mathrm{~B}$ site $(-207$ to $-196 \mathrm{bp})$ of pIL2-293 abrogating the binding of NF- $x \mathrm{~B}$ [30]. The plasmids NF- $x$ B4CAT and TRE2CAT have been described in [17] and harbored four copies of the $x \mathrm{~B}$ and two copies of the AP-1 binding element in front of the tk promoter in pBLCAT2, respectively. Transfections were performed by the DEAE-dextran method [20]. Briefly, $1.5 \times 10^{7}$ cells were resuspended in $2 \mathrm{ml}$ Tris-buffered saline containing $200 \mu \mathrm{g}$ DEAE-dextran, $400 \mu \mathrm{g}$ chloroquine and $10 \mu \mathrm{g}$ DNA of the plasmids. After $24 \mathrm{~h}$, aliquots of batchtransfected cells were either left untreated or stimulated with $100 \mu \mathrm{M} \mathrm{H}_{2} \mathrm{O}_{2}$ for another $18 \mathrm{~h}$. Cell extracts were prepared by three freeze/thaw cycles and normalized for protein content. CAT activity was determined as described [20].

\subsection{Gel retardation assays}

Cells were seeded in a $3 \mathrm{ml}$ volume at $1 \times 10^{6} \mathrm{cells} / \mathrm{ml}$ and stimulated with 50 to $100 \mu \mathrm{M}$ hydrogen peroxide or tetradecanoyl phorbol acetate (TPA, $25 \mathrm{ng} / \mathrm{ml}$ ). After the indicated time points, cells were washed with ice-cold PBS and lysed in a high-salt buffer containing $20 \mathrm{~mm}$ Hepes, pH 7.5, $400 \mathrm{mM} \mathrm{NaCl}, 1 \mathrm{mM} \mathrm{MgCl}_{2}, 0.5 \mathrm{mM}$ EDTA, $0.1 \mathrm{~mm}$ EGTA, $20 \%$ glycerol, $1 \%$ NP40, $1 \mathrm{~mm}$ DTT, $1 \mathrm{~mm}$ PMSF, and $0.01 \%$ aprotinin. Extracts were incubated on 
ice for $10 \mathrm{~min}$ and then cleared by centrifugation. Equal amounts of the extracts (about $10 \mu \mathrm{g}$ crude protein; determined by the Bio-Rad assay kit) were incubated with the NF- $x \mathrm{~B}$ - and AP-1-specific ${ }^{32} \mathrm{P}$-labeled oligonucleotides. Binding reactions were performed in a $20-\mu \mathrm{l}$ volume containing $2-4 \mu \mathrm{l}$ of extract, $4 \mu \mathrm{l} 5 \times$ binding buffer $(20 \mathrm{mM}$ Hepes, pH 7.5, $50 \mathrm{mM} \mathrm{KCl}, 1 \mathrm{mM}$ DTT, $2.5 \mathrm{mM} \mathrm{MgCl}$, $20 \%$ Ficoll $), 2 \mu \mathrm{g}$ poly(dI-dC) as nonspecific competitor DNA, $2 \mu \mathrm{g}$ BSA and $10000-15000 \mathrm{cpm}$ Cerenkov of the labeled oligonucleotide. After $30 \mathrm{~min}$ binding reaction at room temperature, samples were loaded on a $4 \%$ nondenaturing polyacrylamide gel and run in $0.5 \times \mathrm{TBE}$ buffer, pH 8.0. Gels were dried under a gel dryer and exposed to an X-ray film. The sequences of the oligonucleotides used to detect the DNA binding activities of NF- $x$ B and AP- 1 were as follows: NF- $x B: 5^{\prime}-A G C T T C A G-$ AGGGGATTTCCGAGAGG-3'; AP-1: 5'-AGCTTGATGAGTCAGCCGGATC- $3^{\prime}$. The oligonucleotides were annealed with complementary strands containing $5^{\prime}$-overhanging ends and labeled using Klenow polymerase and $[\alpha-32 \mathrm{P}] \mathrm{dCTP}$. The labeled probe was purified from free nucleotides on push columns (Stratagene, Heidelberg, FRG).

\section{Results}

\subsection{Hydrogen peroxide induces activation of NF- $x B$ but not of AP-1}

ESb-L cells were treated with $100 \mu \mathrm{M} \mathrm{H}_{2} \mathrm{O}_{2}$ or the phorbol ester TPA $(25 \mathrm{ng} / \mathrm{ml})$. After different time points lysates were prepared and analyzed for NF- $x \mathrm{~B}$ DNA-binding activity in gel retardation assays. As demonstrated in

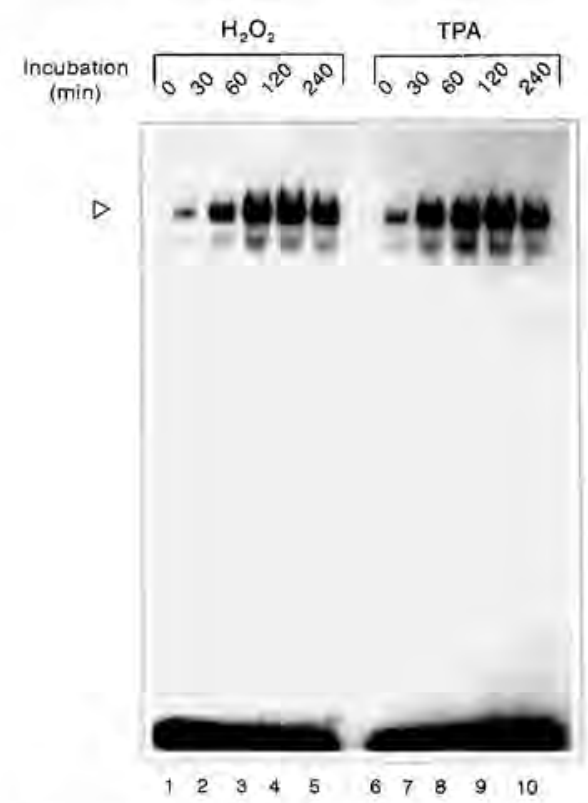

Figure 1. Effect of hydrogen peroxide and TPA on the activation of NF- $x$ B. ESb-L cells were seeded at $1 \times 10^{6} / \mathrm{ml}$ and stimulated with $100 \mu \mathrm{M} \mathrm{H}_{2} \mathrm{O}_{2}$ (left panel) or $25 \mathrm{ng} / \mathrm{ml}$ TPA (right panel). After the indicated time points cells were harvested and cell extracts were analyzed in gel retardation assays using a ${ }^{32} \mathrm{P}$-labeled $\varkappa \mathrm{B}$-specific oligonucleotide. The position of the NF- $x$ B DNA-complex is marked by an arrowhead. Specificity of DNA binding was verified using a 100-fold excess of unlabeled oligonucleotide (not shown).

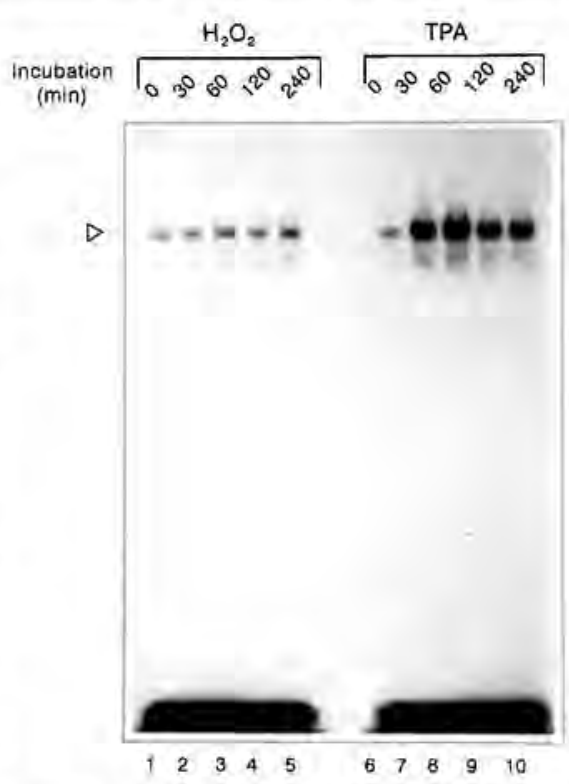

Figure 2. Effect of hydrogen peroxide and TPA on the activation of AP-1. Cells were stimulated as described in Fig. 1. AP-1 DNA binding was analyzed in cell extracts with an AP-1-specific oligonucleotide. The position of the AP-1-specific DNA complex is marked by an arrowhead.

Fig. $1, \mathrm{H}_{2} \mathrm{O}_{2}$ rapidly induced the activation of NF- $x \mathrm{~B}$ within $30 \mathrm{~min}$ of incubation. DNA-binding activity of $\mathrm{NF}-x \mathrm{~B}$ was maximal after 60 min of cell treatment and then gradually declined. For comparison, treatment with TPA, a well-known inducer of NF- $x \mathrm{~B}$ activation, resulted in similar kinetics of NF- $x \mathrm{~B}$ DNA binding (Fig. 1). In contrast to $\mathrm{NF}-x \mathrm{~B}, \mathrm{H}_{2} \mathrm{O}_{2}$ did not lead to a significant activation of AP-1, an important transcription factor involved in various growth stimulatory and differentiation events (Fig. 2). AP-1, however, was strongly activated by treatment with TPA (Fig. 2). These results indicate that $\mathrm{H}_{2} \mathrm{O}_{2}$ selectively induced DNA-binding activity of NF- $x \mathrm{~B}$ in ESb-L cells.

\subsection{Hydrogen peroxide induces IL-2 and IL-2R expression}

Important genes required for $\mathrm{T}$ cell activation include the IL-2 and IL-2R $\alpha$ chain genes. Both genes contain a $x \mathrm{~B}$ cis-regulatory element in their enhancer regions [12]. To analyze whether $\mathrm{H}_{2} \mathrm{O}_{2}$ has a stimulatory effect on gene expression cells were treated with different concentrations of $\mathrm{H}_{2} \mathrm{O}_{2}$. After $48 \mathrm{~h}$ supernatants were harvested and analyzed for $\mathrm{IL}-2$ by measurement of cell proliferation of the IL-2-dependent cell line CTLL-2. As shown in Fig. 3A, micromolar concentrations of $\mathrm{H}_{2} \mathrm{O}_{2}$ significantly enhanced the amount of IL-2 in culture supernatants. Maximal expression was observed with $100 \mu \mathrm{M}$, whereas a higher concentration $(200 \mu \mathrm{M})$ had a weaker effect. Of note, this dose response corresponded to the induction of NF- $x \mathrm{~B}$ DNA binding by $\mathrm{H}_{2} \mathrm{O}_{2}$ (data not shown).

Activation of IL-2 expression was further confirmed at the transcriptional level. Reversed transcribed IL-2 mRNA was clearly detected in samples of cells treated for $12 \mathrm{~h}$ with $100 \mu \mathrm{M} \mathrm{H} \mathrm{H}_{2} \mathrm{O}_{2}$ (Fig. 3B). Amplification of IL-2-specific mRNA, however, was only weakly obtained in nonstimulated cells or in cells treated for only $6 \mathrm{~h}$ with $\mathrm{H}_{2} \mathrm{O}_{2}$. 


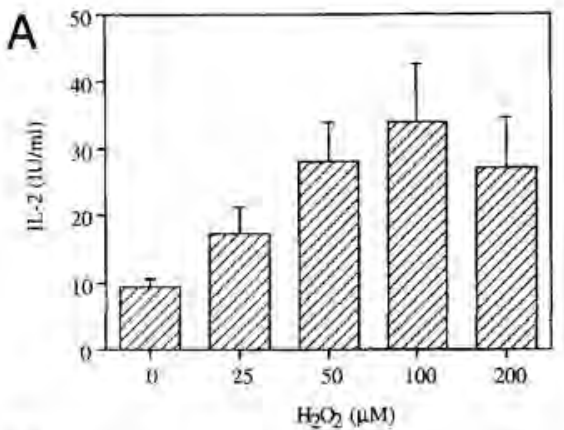

B

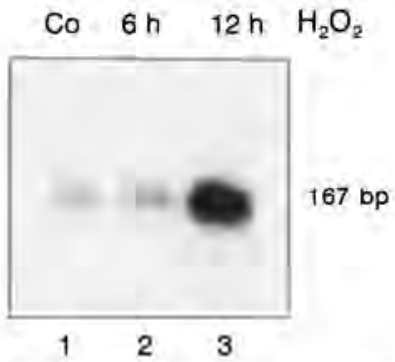

Figure 3. Induction of IL-2 expression by hydrogen peroxide. (A) Effect on IL-2 secretion: Cells were incubated at a density of $5 \times 10^{5} / \mathrm{ml}$ and treated with the indicated concentrations of $\mathrm{H}_{2} \mathrm{O}_{2}$. After $48 \mathrm{~h}$ supernatants were harvested and IL-2 was determined in a proliferation assay using an IL-2 standard. Data represent mean $+1-\mathrm{SD}$. (B) Detection of IL-2-specific mRNA by reversetranscriptase PCR: cells were stimulated with $100 \mu \mathrm{M} \mathrm{H}_{2} \mathrm{O}_{2}$. After the indicated time points total RNA was isolated and reverse transcribed. The cDNA was amplified using mouse IL-2-specific primers. Amplified fragments were hybridized with a radioactive IL-2 probe. Specificity of the amplification product was confirmed by sequencing of the 167 -bp fragment.
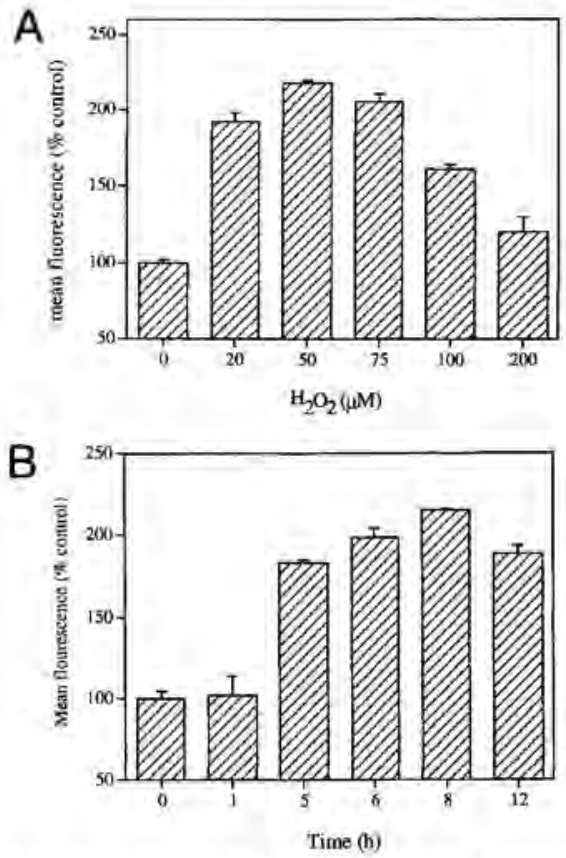

Figure 4. Effect of hydrogen peroxide on IL-2R expression. (A) Dose dependency: cells were cultured with the indicated concentrations of $\mathrm{H}_{2} \mathrm{O}_{2}$ and stained with an $\mathrm{IL}-2 \mathrm{R} \alpha$ chain-specific antibody. Data represent mean fluorescence intensity $+1-$ SD out of three FACS analyses. The fluorescence intensity of unstimulated cells is given as $100 \%$. (B) Time course of IL-2R expression: cells were stimulated with $50 \mu \mathrm{M} \mathrm{H}_{2} \mathrm{O}_{2}$. After the indicated time points IL-2R $\alpha$ chain expression was determined by FACS analysis.
Furthermore $\mathrm{H}_{2} \mathrm{O}_{2}$ induced expression of the IL-2R $\alpha$ chain in a dose-dependent manner. As measured by FACS analysis, expression of IL-2R $\alpha$ chain was strongly enhanced by $50 \mu \mathrm{M} \mathrm{H}_{2} \mathrm{O}_{2}$, whereas higher doses $(75-200 \mu \mathrm{M})$ had a smaller effect (Fig. 4A). Maximal expression of the IL-2R was observed between $5 \mathrm{~h}$ and $12 \mathrm{~h}$ using $50 \mu \mathrm{M} \mathrm{H} \mathrm{H}_{2} \mathrm{O}_{2}$ (Fig. 4B).

\subsection{Induction of $1 \mathrm{~L}-2$ expression is conferred by a $x B$-like element}

The regulatory DNA sequences controlling activation of the IL-2 gene have been localized within a region of about 300 bp upstream of the transcription start site [31]. At least four putative transactivating factors have been identified to bind the IL-2 gene enhancer, including the ubiquitous transcription factors NF- $x \mathrm{~B}$ and $\mathrm{AP}-1$ and the T cellspecific factors NF-AT- 1 and Oct-1. To identify the $\mathrm{H}_{2} \mathrm{O}_{2}$ responsive site within the IL-2 promoter we tested a series

\section{A}
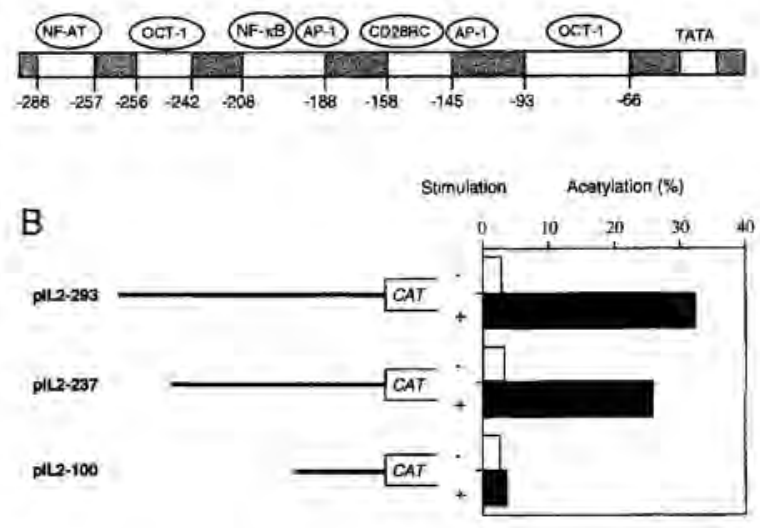

C
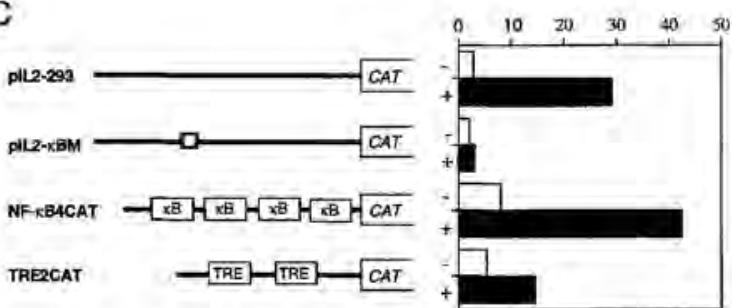

Figure 5. Identification of a hydrogen peroxide-responsive element in the IL-2 promoter. (A) Simplified overview of the IL-2 promoter/enhancer with important functional transcription factor binding sites from region $-300 \mathrm{bp}$ to the transcriptional start site. (B) Effect of $\mathrm{H}_{2} \mathrm{O}_{2}$ on CAT expression of $\mathrm{IL}-2$ enhancer mutants: ESb-L cells were transfected with the wild-type IL-2 enhancer (pIL2-293) and variants containing deletions linked to the CAT gene (the position of the $3^{\prime}$ end of the truncated promoter sequence is indicated). Each pool of transfected cells was devided into two groups: one was stimulated with $100 \mu \mathrm{M} \mathrm{H}_{2} \mathrm{O}_{2}$, the other was left untreated. After $18 \mathrm{~h}$ lysates were prepared and promoter activity was measured in CAT assays. CAT activity is indicated as percentage of acetylation of radioactive chloramphenicol. Results from one representative out of three experiments are shown. Variation was less than $16 \%$. (C) Effect of $\mathrm{H}_{2} \mathrm{O}_{2}$ on CAT expression of the wild-type IL-2 (pIL2-293), of a mutant in the $x B$ (site (pIL2-xBM) and of an NF- $x \mathrm{~B}-(\mathrm{NF}-x \mathrm{~B} 4 \mathrm{CAT})$ and AP-1-(TRE2CAT) driven CAT construct. Promoter activity was measured as described in (B). Values are representative of two independent transfections. Variation was less than $12 \%$. 
of deletion and substitution mutants directing expression of the CAT enzyme. Disconnection of the IL-2 enhancer region from the $\mathrm{IL}-2$ gene further allowed the analysis of transcriptional regulation without interfering effects on IL-2 mRNA stabilization.

When the reporter gene plasmid pIL2-293 harboring the IL-2 enhancer from position -293 to -7 bp was introduced into $\mathrm{ESb}-\mathrm{L}$ cells, hydrogen peroxide induced an about 12-fold increase in CAT expression (Fig. 5B). Deletion of the distal part of the IL-2 promoter, including the NF-AT and distal Oct-binding site in the plasmid pIL2-237, had only weak effects on $\mathrm{H}_{2} \mathrm{O}_{2}$ responsiveness of the $\mathrm{IL}-2$ promoter. Expression of the deletion construct pIL2-100, however, was not induced by $\mathrm{H}_{2} \mathrm{O}_{2}$, indicating that the $\mathrm{H}_{2} \mathrm{O}_{2}$-responsive site was localized between -237 and $-100 \mathrm{bp}$, a region containing an NF- $x \mathrm{~B}$ and AP-1 binding element. Since gel retardation assays have revealed that $\mathrm{H}_{2} \mathrm{O}_{2}$ activated NF- $x$ B but not AP-1 DNA binding we next performed transfections with a plasmid in which the NF- $x \mathrm{~B}$ binding site $(-207$ to $-196 \mathrm{bp})$ was rendered nonfunctional by a site-specific mutation. As shown in Fig. $5 \mathrm{C}$, mutation of the $x \mathrm{~B}$ site nearly completely abrogated the stimulating effect of $\mathrm{H}_{2} \mathrm{O}_{2}$. As anticipated, expression of a multimeric $x \mathrm{~B}-\mathrm{CAT}$ plasmid $(\mathrm{NF}-x \mathrm{~B} 4 \mathrm{CAT})$ was also strongly increased by $\mathrm{H}_{2} \mathrm{O}_{2}$ (about 11 -fold) whereas an AP-1 driven construct (TRE2CAT) and the parental vector were only weakly or not responsive. Thus, these results demonstrate that the major locus of $\mathrm{H}_{2} \mathrm{O}_{2}$ responsiveness is likely to be the $x \mathrm{~B}$ site within the IL-2 promoter.

\subsection{Effects of hydrogen peroxide on cell proliferation}

Since ESb-L cells respond to $\mathrm{H}_{2} \mathrm{O}_{2}$ by an increase of NF- $x \mathrm{~B}$ activation as well as the induction of IL-2 and $I L-2 R$ expression, we further analyzed its effect on cell proliferation. Cells were treated with increasing concentrations of $\mathrm{H}_{2} \mathrm{O}_{2}$ and DNA synthesis was determined after $48 \mathrm{~h}$. As shown in Fig. 6A, increasing concentrations of $\mathrm{H}_{2} \mathrm{O}_{2}$ were
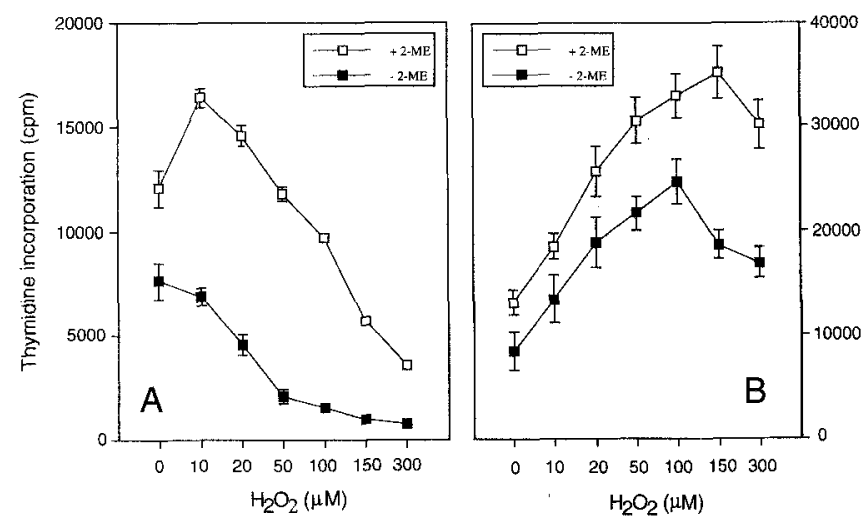

Figure 6. Effects of hydrogen peroxide on cell proliferation. (A) Influence of 2-mercaptoethanol (2-ME): cells were stimulated with the indicated concentrations of $\mathrm{H}_{2} \mathrm{O}_{2}$ in the presence or absence of $30 \mu \mathrm{M}$ mercaptoethanol. After $48 \mathrm{~h}$ cells were pulsed with [ $\left.{ }^{3} \mathrm{H}\right]$ thymidine and incubated for further $6 \mathrm{~h}$. (B) Effects of hydrogen peroxide in the presence of catalase: cells were stimulated with different concentrations of $\mathrm{H}_{2} \mathrm{O}_{2}$ in the presence or absence of 2-mercaptoethanol (2-ME). Two minutes after the addition of $\mathrm{H}_{2} \mathrm{O}_{2}$ cultures received catalase $(15000 \mathrm{U} / \mathrm{ml})$. Incubation was continued as described in (A). largely growth-inhibitory and almost completely blocked thymidine incorporation. However, we noted that small concentrations between 10 and $20 \mu \mathrm{M}$ reproducibly augmented proliferation of ESb-L cells. This enhancing effect was only observed in cell culture medium containing 2-mercaptoethanol. In the absence of reducing thiols cell proliferation was markedly reduced even without the addition of $\mathrm{H}_{2} \mathrm{O}_{2}$. These observations suggested that small concentrations of $\mathrm{H}_{2} \mathrm{O}_{2}$ may induce proliferative events when cells are kept in a reducing environment. We, therefore, analyzed the effect of a very short-term exposure of cells to $\mathrm{H}_{2} \mathrm{O}_{2}$ on proliferation. To this end, ESb-L cells were treated with different concentrations of $\mathrm{H}_{2} \mathrm{O}_{2}$ followed by its inactivation through catalase added $2 \mathrm{~min}$ later. Under these conditions, $\mathrm{H}_{2} \mathrm{O}_{2}$ increased cell proliferation in a dose-dependent manner even at high concentrations (Fig. 6B). In the presence of catalase, $\mathrm{H}_{2} \mathrm{O}_{2}$ was also mitogenic in the absence of thiols in the culture medium. Addition of catalase alone, however, had no significant effects. These observations suggest that, although prooxidant conditions may be unfavorable for cell growth, a brief exposure to prooxidant conditions provides a signal to initialize cell division.

\section{Discussion}

During the immune response neutrophils and other cell types produce large amounts of reactive oxygen intermediates (ROI). While it is well established that ROI play an important role as an antimicrobial defense mechanism, limited information exists about the involvement of ROI in other cellular processes, such as signal transduction, gene expression or the cell cycle. In the present study we, therefore, investigated the effects of hydrogen peroxide on various aspects of $T$ lymphocyte activation. It is shown that exposure of $\mathrm{T}$ cell lymphoma ESb-L cells to $\mathrm{H}_{2} \mathrm{O}_{2}$ has multiple effects including the activation of transcription factor NF- $x B$, induction of IL-2 and the IL-2R gene expression and stimulation of cell proliferation under defined conditions. These findings support previous data obtained by us and others suggesting that ROI are involved in important processes related to signal transduction and gene expression [13-18].

It has been shown that Jurkat $\mathrm{T}$ cells respond to $\mathrm{H}_{2} \mathrm{O}_{2}$ by the rapid activation of $\mathrm{NF}-\varkappa \mathrm{B}$ [13]. Several reports have further shown that NF- $x \mathrm{~B}$ activation in response to TPA or cytokines is commonly inhibited by various antioxidants suggesting that $\mathrm{NF}-x \mathrm{~B}$ is a prooxidant-responsive transcription factor [13-18]. We observed that induction of NF- $x \mathrm{~B}$ DNA-binding activity followed similar kinetics and intensity as stimulation by TPA. In contrast to phorbol esters, $\mathrm{H}_{2} \mathrm{O}_{2}$ was unable to activate AP-1 DNA binding in ESb-L cells. This is consistent with the observation that, although $\mathrm{H}_{2} \mathrm{O}_{2}$ may lead to the rapid expression of c-jun and $\mathrm{c}-\mathrm{fos}$, AP-1 DNA binding is not or only weakly activated $[11,18]$.

NF- $x \mathrm{~B}$ is known to control the expression of several immunoregulatory gene products [12]. Two important genes of the immune response, the IL-2 and IL-2R $\alpha$ chain gene, contain $x \mathrm{~B}$-like motifs in their promoter regions [12]. While the regulatory role of $N F-x B$ in $I L-2 R$ expression is well established, its functional importance for transcrip- 
tional activation of the $\mathrm{IL}-2$ gene is less clear and presumably dependent on the nature of the activating signal $[1,32]$. NF- $x$ B-like proteins have been shown to control IL-2 expression in response to costimulation via the T cell surface receptor CD28 and the IL-1R $[1,30,33]$. Other transcription factors, such as AP-1, Oct-1 or NF-AT, may regulate gene expression of $1 \mathrm{~L}-2$ in response to certain other stimuli [1]. Since these transcription factors, however, are not activated by prooxidants, it is likely that $\mathrm{H}_{2} \mathrm{O}_{2}$-induced IL-2 expression is exclusively or mainly conferred by a $x \mathrm{~B}$-like element. This conclusion is further supported by the analysis of the IL-2 promoter. Promoter activity was activated by $\mathrm{H}_{2} \mathrm{O}_{2}$ in the wild-type IL-2 promoter but not in a construct lacking a functional NF- $x \mathrm{~B}$ binding site. Thus, the $\mathrm{H}_{2} \mathrm{O}_{2}$-responsive site is likely to be the $x \mathrm{~B}$ element within the $\mathrm{IL}-2$ promoter.

Since IL-2 and IL-2R gene expression are important $T$ cell activation events, we further analyzed the effects of prooxidants on cell growth. In contrast to the positive effects of $\mathrm{H}_{2} \mathrm{O}_{2}$ observed on gene expression, exposure of ESb-L cells to $\mathrm{H}_{2} \mathrm{O}_{2}$ was largely growth-inhibitory. This is consistent with the general requirement of thiols for lymphoid cells and with reports that withdrawal of thiols inhibits lymphocyte proliferation [25-27]. However, we observed that in a limited range of small $\mathrm{H}_{2} \mathrm{O}_{2}$ concentrations proliferation was enhanced when the cells were kept in a reducing environment, i.e. the presence of 2-mercaptoethanol. This indicated that, even though peroxides were cytotoxic, a short exposure to a prooxidant might induce DNAreplicative events. This assumption was confirmed by experiments using catalase. Increasing amounts of $\mathrm{H}_{2} \mathrm{O}_{2}$ were strongly growth-promoting provided that $\mathrm{H}_{2} \mathrm{O}_{2}$ was immediately inactivated by the addition of catalase.

It has been shown that ROI may exert mitogenic effects in some cell types, such as fibroblasts or smooth muscle cells, which are not dependent on reducing conditions $[34,35]$. In T lymphocytes, however, prooxidants have been found to be essentially growth-inhibitory and antioxidants, such as mercaptoethanol, cysteine or glutathione esters are required for optimal growth conditions. The present study demonstrates that ROI may also be mitogenic in those cells that normally favor reducing conditions for cell growth. It is possible that a brief exposure to ROI induces the synthesis of growth factors or antioxidant enzymes that are beneficial for cell growth. Since proliferation of ESb-L cells, however, is IL-2 independent [29], it is unlikely that mitogenic effects of $\mathrm{H}_{2} \mathrm{O}_{2}$ are linked to the induction of IL-2 and IL-2R expression. Another possibility is that $\mathrm{H}_{2} \mathrm{O}_{2}$ directly affects events required for initiation of DNA synthesis and commitment of T cells to enter the cell cycle. Accordingly, we observed that in synchronized cultures, $\mathrm{H}_{2} \mathrm{O}_{2}$ only had proliferative effects in early phases of the cell cycle (data not shown). Studies of the murine T cell clone D10.G4.1 have revealed that hydrogen peroxide causes a marked augmentation of DNA synthesis in the absence but not in the presence of mitogens suggesting that a mitogenic stimulus may either bypass the requirement for ROI or by itself induce ROI formation [4]. In addition, $\mathrm{H}_{2} \mathrm{O}_{2}$ has been found to activate essential steps required for growth competence, such as activation of Src kinases or phosphorylation of S6 ribosomal protein [36-38]. Thus, ROI may act as a competence signal for cells to undergo cell division.

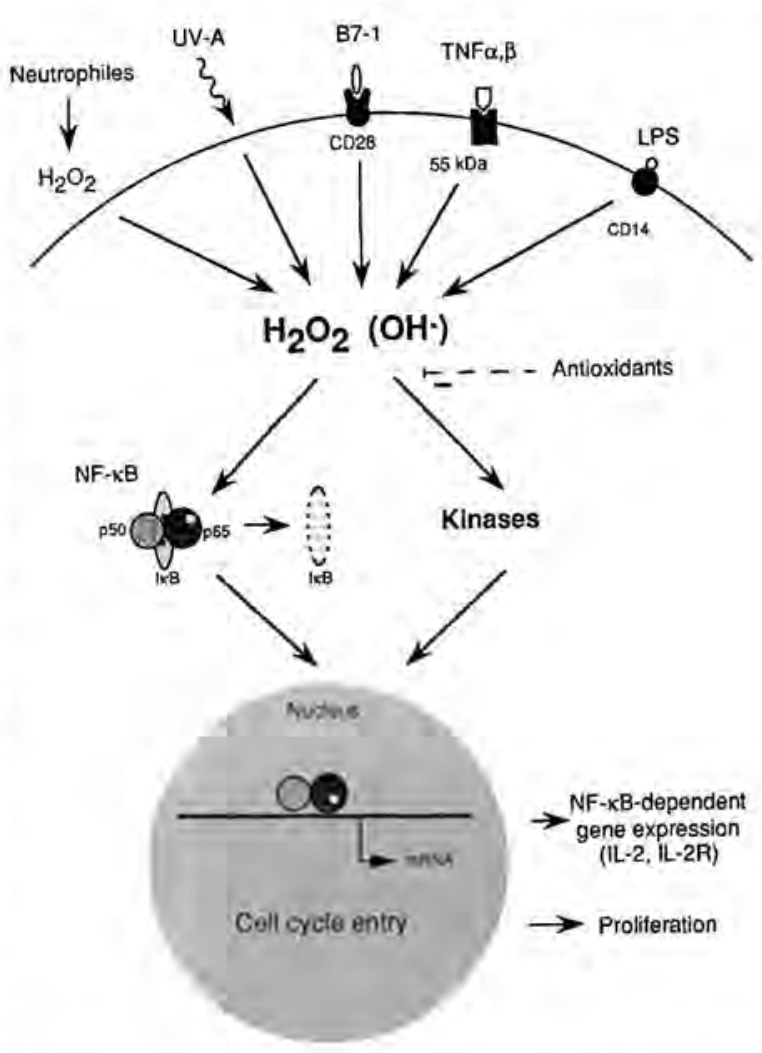

Figure 7. Scheme of intracellular messenger functions of hydrogen peroxide.Various T cell stimuli increase the intracellular amount of $\mathrm{H}_{2} \mathrm{O}_{2}$ or other ROI, such as hydroxyl radicals $(\mathrm{OH} \cdot)$. ROI trigger the activation of $\mathrm{NF}-x \mathrm{~B}$ which leads to the inducible expression of $\mathrm{IL}-2$ or the IL-2R $\alpha$ chain genes. Secondly, $\mathrm{H}_{2} \mathrm{O}_{2}$, secreted by neutrophils or produced intracellularly in response to $\mathrm{T}$ cell signals, may be involved in the initiation of the cell cycle leading to $\mathrm{T}$ cell proliferation.

The concentrations of $\mathrm{H}_{2} \mathrm{O}_{2}$ required to exert effects on $\mathrm{T}$ cell function can be assumed to be in a physiological range, particularly during inflammatory processes $[39,40]$. As depicted in Fig. 7, several physiological stimuli, such as TNF, LPS or the CD28 receptor, have been reported to trigger the intracellular formation of $\mathrm{H}_{2} \mathrm{O}_{2}$ and by this way control gene-regulatory processes $[19,20,41,42]$. In addition, mitogenic stimulation of $T$ cells has been observed to result in a rapid and transient increase of ROI formation ([43] and M. Los et al., unpublished results), suggesting that a short prooxidative shift may provide a signal to enter the cell cycle.Thus, ROI seem to be potent and widely used second messengers involved in various aspects of $\mathrm{T}$ cell activation. Conversely, gene expression induced by ROI or proinflammatory stimuli must be balanced and counteracted by endogenous antioxidants, most importantly glutathione and thioredoxin [14-18]. Dysregulation of the intracellular redox state observed in HIV infection and other diseases is, therefore, likely to be involved in disorders of $\mathrm{T}$ cell functions $[44,45]$.

The authors wish to thank Drs. P. Von Hoegen and V. Schirrmacher for kindly providing ESb-L cells.

Received October 11, 1994; in revised form November 9, 1994; accepted November 9, 1994. 


\section{References}

1 Ullman, K. S., Northrop, J. P., Verweij, C. L. and Crabtree, G. R., Annu. Rev. Immunol. 1990. 8: 421.

2 Halliwell, B. and Gutteridge, J. M. C., Methods Enzymol. 1990. 186: 1.

3 Schulze-Osthoff, K. and Baeuerle, P. A., Adv. Mol. Cell Biol. 1995. In press.

4 Dröge, W., Mihm, S., Bockstette, M. and Roth, S., Methods Enzymol. 1994. 234: 135.

5 Roth, S. and Dröge, W., Cell. Immunol. 1987. 108: 417.

6 Roth, S. and Dröge, W., Eur. J. Immunol. 1991. 21: 1933.

7 Eugui, E. M., DeLustro, B., Rouhafza, S., Illnicka, M., Lee, S. W., Wilhelm, R. and Allsion, A., Int. Immunol. 1994. 6: 409.

8 Lo, S. K., Janakidevi, K., Lai, L. and Malik, A. B., Am. J. Physiol. 1993. 264: L406.

9 Marui, N., Offermann, M. K., Swerlick, R., Kunsch, C., Rosen, C. A., Ahmad, M., Alexander, R. W. and Medford, R. M., J. Clin. Invest. 1993. 92: 1866.

10 Crawford, D., Zbinden, J., Amstad, P. and Cerutti, P. A., Oncogene 1988. 3: 27.

11 Devary, Y., Gottlieb, R. A., Smeal, T. and Karin, M., Mol. Cell. Biol. 1991. 11: 2804.

12 Baeuerle, P. A. and Henkel, T., Annu. Rev. Immunol. 1994. 12: 141.

13 Schreck, R., Rieber, P. and Baeuerle, P. A., EMBO J. 1991. 10: 2247.

14 Mihm, S., Ennen, J., Pessara, U., Kurth, R. and Dröge, W., AIDS 1991. 5: 497.

15 Staal, F. J. T., Roederer, M., Herzenberg, L. A. and Herzenberg, L. A., Proc. Natl. Acad. Sci. USA 1990. 87: 9943.

16 Schulze-Osthoff, K., Beyaert, R.,Vandevoorde,V., Haegeman, G. and Fiers, W., EMBO J. 1993. 12: 3095.

17 Schenk, H., Klein, M., Erdbrügger,W., Dröge,W. and SchulzeOsthoff, K., Proc. Natl. Acad. Sci. USA 1994. 91: 1672.

18 Meyer, M., Schreck, R. and Baeuerle, P. A., EMBO J. 1993. 12: 2005.

19 Costello, R., Lipcey, C., Algarté, M., Cerdan, C., Baeuerle, P. A., Olive, D. and Imbert, J., Cell Growth Diff. 1993. 4: 329.

20 Los, M., Dröge, W. and Schulze-Osthoff, K., Biochem. J. 1994. 302: 119.

21 Novogradsky, A., Ravid, A., Rubin, A. L. and Stenzel, K. H., Proc. Natl. Acad. Sci. USA 1982. 79: 1171.

22 Chaudri, G., Hunt, N. H., Clark, I. A. and Ceredic, R., Cell. Immunol. 1988. 115: 204.
23 Dornand, J. and Gerber, M., Immunology 1989. 68: 384.

24 Eylar, E., Rivera-Quinnones, C., Molina, C., Baez, I., Molina, F. and Mercado, C., Int. Immunol. 1993. 5: 97.

25 Smyth, M. J., J. Immunol. 1991. 146: 1921.

26 Suthanthiran, M., Anderson, M. E., Sharma, V. K. and Meister, A., Proc. Natl. Acad. Sci. USA 1990. 87: 3343.

27 Fidelus, R. K. and Tsan, M. F., Cell. Immunol. 1986. 97: 155.

28 Gmünder, H. and Dröge, W., Cell. Immunol. 1991. 138: 229.

29 Schirrmacher,V., Ahlert, T., Heicappell, R., Appelhans, B. and Von Hoegen, P., Cancer Rev. 1986. 5: 19.

30 Stricker, K., Serfling, E., Krammer, P. H. and Falk, W., Eur. J. Immunol. 1993. 23: 1475.

31 Serfling, E., Barthelmäs, R., Pfeuffer, I., Schenk, B., Zarius, S., Swoboda, R., Mercurio, F. and Karin, M., EMBOJ. 1989. 8: 465.

32 Cross, S. L., Halden, N. F., Leonard, M. J. and Leonard, W. J., Science 1989. 244: 466.

33 Ghosh, P., Tan, T.-H., Rice, N. A., Sica, A. and Young, H. A., Proc. Natl. Acad. Sci. USA 1993. 90: 1696.

34 Murrell, G. A. C., Francis, M. J. O. and Bromley, L., Biochem. J. 1990. 265: 659.

35 Rao, N. and Berk, B. C., Circ. Res. 1992. 70: 593.

36 Nakamura, K., Hori, T., Sato, N., Sugie, K., Kawakami, T. and Yodoi, J., Oncogene 1993. 8: 3133.

37 Schieven, G. L., Kirihara, J. M., Myers, D. E., Ledbetter, J. A. and Uckun, F. M., Blood 1993. 82: 1212.

38 Larrson, R. and Cerutti, P., J. Biol. Chem. 1988. 263: 17452.

39 Nathan, C. F. and Root, R. K., J. Exp. Med. 1977. 146: 1648.

40 Keisari, Y., Braun, L. and Flescher, E., Immunobiology 1983. 165: 77.

41 Schulze-Osthoff, K., Bakker, A. C., Vanhaesebroeck, B., Beyaert, R., Jacobs, W. and Fiers, W., J. Biol. Chem. 1992. 267 : 5317.

42 Ziegler-Heitbrock, H. W. L., Sternsdorf, T., Liese, J., Belohradsky, B., Weber, C., Wedel, A., Schreck, R., Baeuerle, P. and Ströbel, M., J. Immunol. 1993. 151: 6986.

43 Hunt, N. H., van Reyk, D. M., Fragonas, J. C., Jeitner, T. M. and Goldstone, S. D., in Pasquier, C., Olivier, R. Y., Auclair, C., Packer, L. (Eds.), Oxidative Stress, Cell Activation and Viral Infection, Birkhäuser Verlag, Basel, 1994, p. 237.

44 Dröge, W., Eck, H. P. and Mihm, S., Immunol. Today 1992. 14: 211.

45 Greespan, H. C. and Aruoma, O. I., Immunol. Today 1994. 15: 209. 